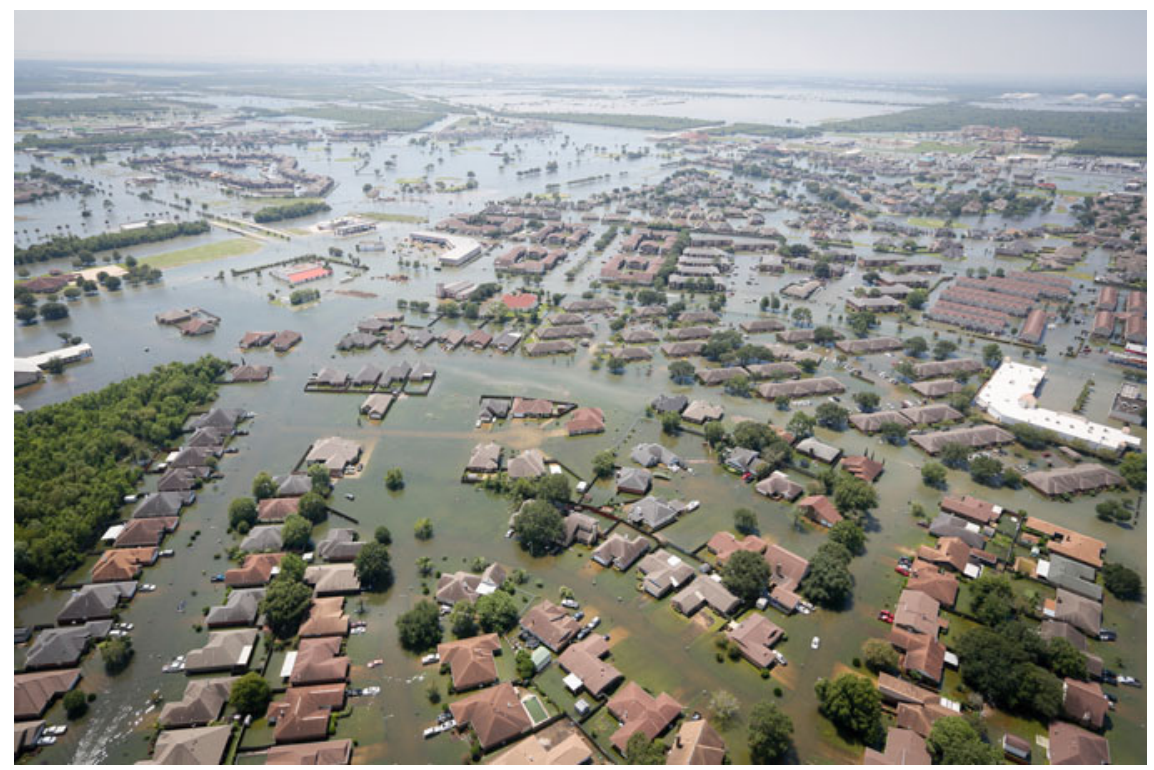

Flooding in Port Arthur, Texas on August 31, Wikimedia, SC National Guard-170831-Z-AH923081 (https://www.flickr.com/photos/scguard/36564448210/), Public Domain 


\title{
Chapter 21 \\ Toward a Cultural Heritage \\ of Adaptation: A Plea to Embrace \\ the Heritage of a Culture of Risk, \\ Vulnerability and Adaptation
}

\section{Han Meyer}

\begin{abstract}
We need to tell a new story about urbanizing delta regions. Historically, large-scale 'iconic' hydraulic works and modern industrial ports have been celebrated as showing the power of humans to control and subject nature. The emphasis on this part of cultural heritage tends to bury the remains of engineering and urban development of the previous periods and to erase the ebb and flow of natural processes in the earlier landscape. Instead of emphasizing resistance against nature and victories over nature, we need to embrace mitigation, adaptation, and uncertainty. Many urbanized delta regions, including the Dutch delta, have a rich history of such approaches. We can learn from that history, from the successes as well as from the failures. This chapter is a plea to embrace the dynamic and evolutionary character of delta regions and the cultures of adaptation which have been developed over many centuries. It means that another policy concerning cultural heritage should be stimulated in urbanizing deltas, fostering a heritage with an adaptive approach, not as a complete departure from present ways of doing things, but as a new stage in a centuries-long tradition.
\end{abstract}

Keywords Heritage of adaptation $\cdot$ Risk $\cdot$ Vulnerability $\cdot$ Uncertainty $\cdot$ Formative power of deltas

\section{Introduction}

Mitigation and adaptation are the themes that will dominate the urban agenda of the twenty-first century. Mitigation means changing our energy production and consumption, land use, food production, and waste disposal so that climate change and exhaustion of the earth will not lead to disaster. Adaptation means adjusting our planning and consumption to the already irreversible effects of climate change, like accelerating sea-level rise. And because we do not know exactly how conditions will change in the future, we must learn to live in uncertainty.

\footnotetext{
H. Meyer $(\bowtie)$

Delft University of Technology, Delft, The Netherlands

e-mail: v.j.meyer@tudelft.nl 
Mitigation, adaptation, uncertainty: It seems that these themes are new and that they mean a fundamental break with the policies and strategies of the past. That is the dominating story, especially concerning urbanizing deltas. These regions have been developed into important hubs of the fossil fuel economy during the last 150 years. The transshipment, storage, and processing of fossil fuels are required large industrial and port areas and a sophisticated infrastructure of deep sea ports, quay walls, navigation channels, and flood defense systems. Mitigation, including the transition toward new energy systems, will have great impact on both land use and infrastructure in these regions. Next to it, adapting to the effects of climate change, like rising sea level and increasing peak discharges of rivers, requires a fundamental revision of flood defense strategies. Today's uncertain circumstances seem to call for these sharp breaks with the long-term spatial and technical arrangements of delta regions.

But presenting the adaptive approach as a new approach, breaking with traditions, makes it vulnerable and easy to attack by opponents. Most of the national cultural heritage in the Netherlands (and there are many similar examples in other countries) conveys a message that it is possible to resist, control, and subdue nature: We did it for centuries, with increasing success, so why should we s change to another approach? These monuments are cherished as characteristic reminders of a strong collective culture which has claimed land from the sea step-by-step, making untamed marshlands submit to human will. In particular, the large hydraulic works of the nineteenth and twentieth century are celebrated as important chapters of a story on the supremacy of a nation state, a new technology of steam power, fossil energy, and an industrial economy, tools that definitively control nature (Meyer 2017).

In this chapter, I argue that there is another story about dealing with water throughout the centuries, which is not so different from the 'new' policy of adaptation and dealing with uncertainty. It is a story about awareness of risks, uncertainty, and vulnerability; it is also a story about attempts to understand the dynamics of nature, about awareness of changing conditions and the need to adapt to these changes. If we look carefully at the history of urbanization in urban deltas, we can discover many interesting examples of how people tried to understand the dynamics of these water landscapes and how to make use of them. If we open our eyes to this history, it might be possible to learn from it for the future and to consider the current agenda not as a break, but as a new chapter in a long tradition of continuous adaptation. This attention to another cultural heritage is relevant not only for the Netherlands, but for many other urbanized deltas in the world.

\section{Working with the Formative Power of Delta System}

Deltas are complex and dynamic systems, the products of the convergences of rivers and the sea, where sea currents, tides, discharges, wind, sediment deposition, and erosion formed deltaic plains of sandy beaches, dunes, and alluvial lowlands. Vegetation in these lowlands compressed into layers of peat, part of the natural process of land making. This process of land making can be recognized in all deltas in the 
world, in many different variations. We can distinguish between different types of delta according to the source of their formative sediment: river-dominated deltas, wave-dominated deltas, and tide-dominated deltas (Bradshaw and Weaver 1995).

Regardless of type, deltas are the richest ecosystems of the world. As gradual transitions between land and water and between salt and fresh water, they are the biotopes and nurseries of many species that are crucial for the ecological balance of the world's rivers and oceans. Next to their ecological value in terms of biological productivity and diversity, these ecosystems offer significant economic value in ecosystem services: coastal protection, maintenance of fisheries and wildlife, erosion control, water catchment and purification, carbon sequestration, nutrient cycling, tourism, recreation, education, and research.

Cultures and technologies rose with an awareness of these dynamic processes of the delta. In the Netherlands, the sixteenth-century engineer Andries Vierlingh published a Tractaet van Dyckagie ('Treatise on Diking') on the reclamation of land and the construction of dikes, based on learning natural dynamics and making use of them (de Hullu and Verhoeven 1920). Vierlingh explained how original creeks in reclaimed land could be used to drain the land, and how the form, construction, and positioning of dikes might lessen the power of storm surges. His book became an influential manual in reclaiming land and dike construction in the Dutch delta of the sixteenth and seventeenth centuries. Similarly, engineers like Simon Stevin (1548-1620), Jan A. Leeghwater (1575-1650), and Nicolaus Cruquius (1678-1754) researched currents, erosion, and sedimentation (Meyer 2017). They were aware of the dynamic character of these processes, and how they changed conditions for land use and urbanization-indeed, they witnessed many disastrous floods themselves. Buisman counts at least 48 serious floods in the Dutch low lands from the eleventh to the twentieth century, each flood resulting in many victims, land loss, and economic damage (Buisman 1995/2016). Today, we tend to forget all these times that nature hit back, reconquering reclaimed land. Yet in the Southwest delta alone, the sea swallowed more than one hundred villages and small towns over the course of centuries (Stulp 2011). Some traces of these disappeared villages and towns haunt the landscape, like the Plompe Toren ('clumsy tower'), the only remnant of the village Koudekerke along the border of the East Scheldt (Fig. 1). Vierlingh warned his readers to be aware of the risks of reclamation and to avoid reckless thinking that nature can be conquered and controlled.

Along the coastline of Holland, as well as along the coasts of the previous Zuiderzee and the Wadden islands, many villages and towns faced unstoppable coastal erosion and an encroaching flood line. These forced them to move further inland. Towns like Egmond and Monster had to rebuild their urban cores in several times across the centuries, after disastrous floods.

Along with floods, ongoing sedimentation was a substantial problem for many cities. A rather famous example is the Flemish city of Bruges, an important seaport until the fourteenth century. After that, the accessibility of the port decreased seriously because of the silting up of the Zwin estuary. The town of Damme, on the same estuary but more seaward, took over the port role from Bruges. When the channel to Damme also silted up, the more seaward located towns of Sluis and St. Anna ter Muiden took 


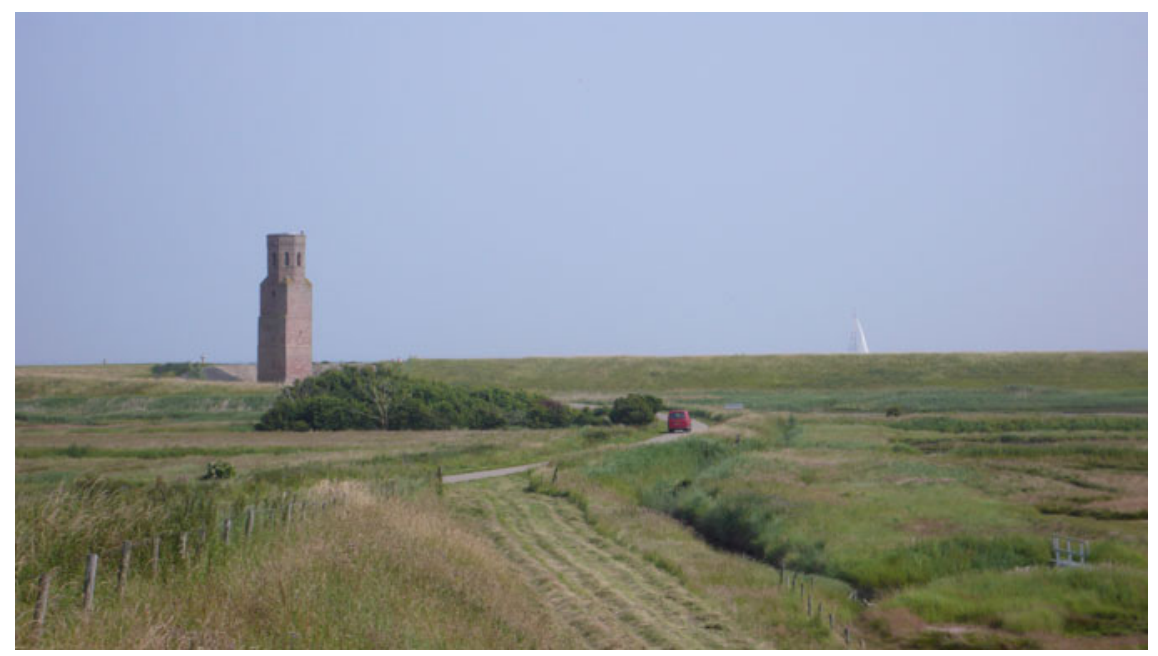

Fig. 1 Plompe Toren ('Clumsy Tower') in the Dutch Southwest delta: a remain of a drowned town. Photograph by Han Meyer; released under a Creative Commons Attribution-NonCommercialNoDerivatives 4.0 International License

over the role of seaports. Finally, when the Zwin silted up completely and Sluis and St. Anna ter Muiden became inaccessible, these towns had to change their economy to agriculture.

The Dutch town Goedereede faced the same fate in the sixteenth and seventeenth century. The famous mapmaker Jacob van Deventer (1505-1575) showed its harbor connected with the sea (Fig. 2). But over the following centuries, the town battled increasing silt by digging a canal to deeper water, as did many other seaports in the Rhine-Meuse-Scheldt delta. Finally, however, the sediment could not be halted and Goedereede lost its position as important seaport (Fig. 3). Today, this small town's remarkable mixture of merchants' houses and farm buildings represents its forced but successful transition from a port economy to an agricultural economy during the seventeenth and eighteenth centuries (Fig. 4).

Not only individual towns and villages, but the whole pattern of urban settlements in the Western part of the Netherlands had to adapt to changing conditions several times. Until the eleventh century, the main string of urban settlements was organized alongside the borders of a branch of the River Rhine now named Oude Rijn (Old Rhine). This branch of the river was then the main artery for transport and for the discharge of the drained water from the polders of central Holland. But the mouth of this branch starting silting up in the ninth century, and people had to reroute both transport and drainage. New urban settlements arose along the borders of the Southwest delta and the Zuiderzee: The main body of the Rhine and also the Meuse River now discharged drained water from central Holland into the estuaries of the Southwest delta; in the Northern part of the Netherlands, storm surges had created the Zuiderzee as a new inland sea that people could use for drainage and transport. 


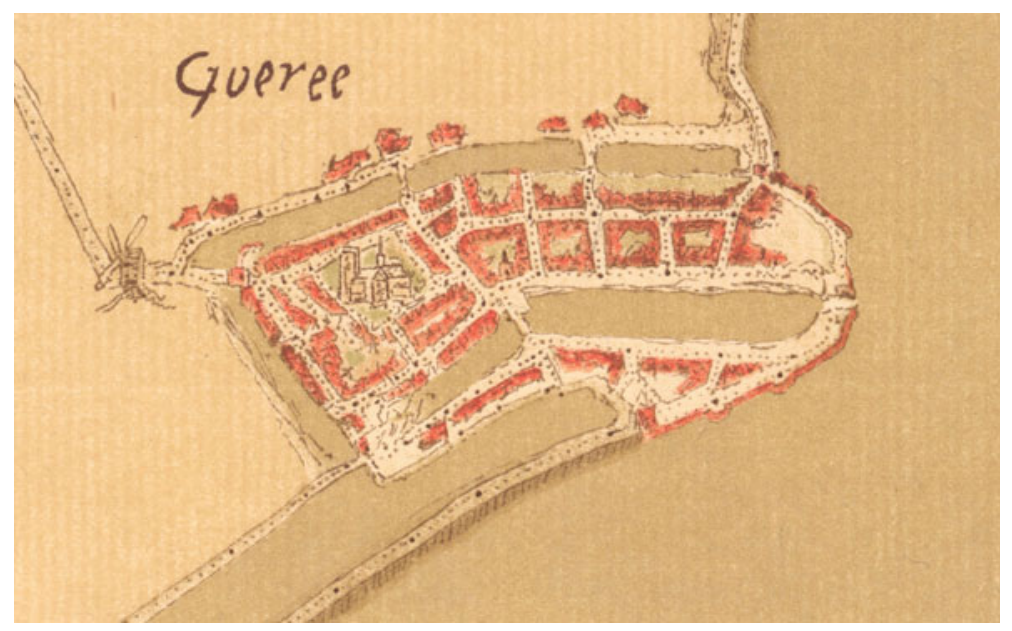

Fig. 2 Town plan of Goedereede, ca. 1550 by Jacob van Deventer; released under a Creative Commons Attribution-NonCommercial-NoDerivatives 4.0 International License

This complete spatial reversal turned central Holland inside out in a period of two centuries (Meyer 2017).

In other deltas, we can find comparable stories of the interrelationship of natural dynamics and the development of human settlements. The American agricultural scientist Franklin Hiram King was fascinated by what he found when he travelled along the coasts of Japan, China, and Korea in the early twentieth century: a strong and centuries-old agricultural culture practicing an economic system which we would call a 'circular economy' today. The communities of the towns and villages used all the waste, including all human feces, to fertilize the land and to stabilize new land created by river sediment (King 1911). Like Vierlingh in the Netherlands, they built on the natural processes of land making by rivers and sea.

In the city of New Orleans in the Mississippi River delta, the 'muddy river' left thick layers of sediment behind on the embankments after each high water event. These layers of mud were considered a public amenity and collected by the Public Works Department to elevate the streets, while private citizens used the mud to elevate their own properties. (Campanella 2006, 2010; Colten 2000). To protect the river mud as a public amenity, the city prohibited building on the waterfront itself. This is the main reason why New Orleans was one of the few American port cities with an open, public waterfront in the nineteenth century (Upton 2008) (Fig. 5).

Thus, awareness of the formative power of delta systems has been important from an ecological point of view, to protect the biodiversity in these areas. It has been especially important to our ability to maintain our cities, ports, and agricultural landscapes in these dynamic territories. 

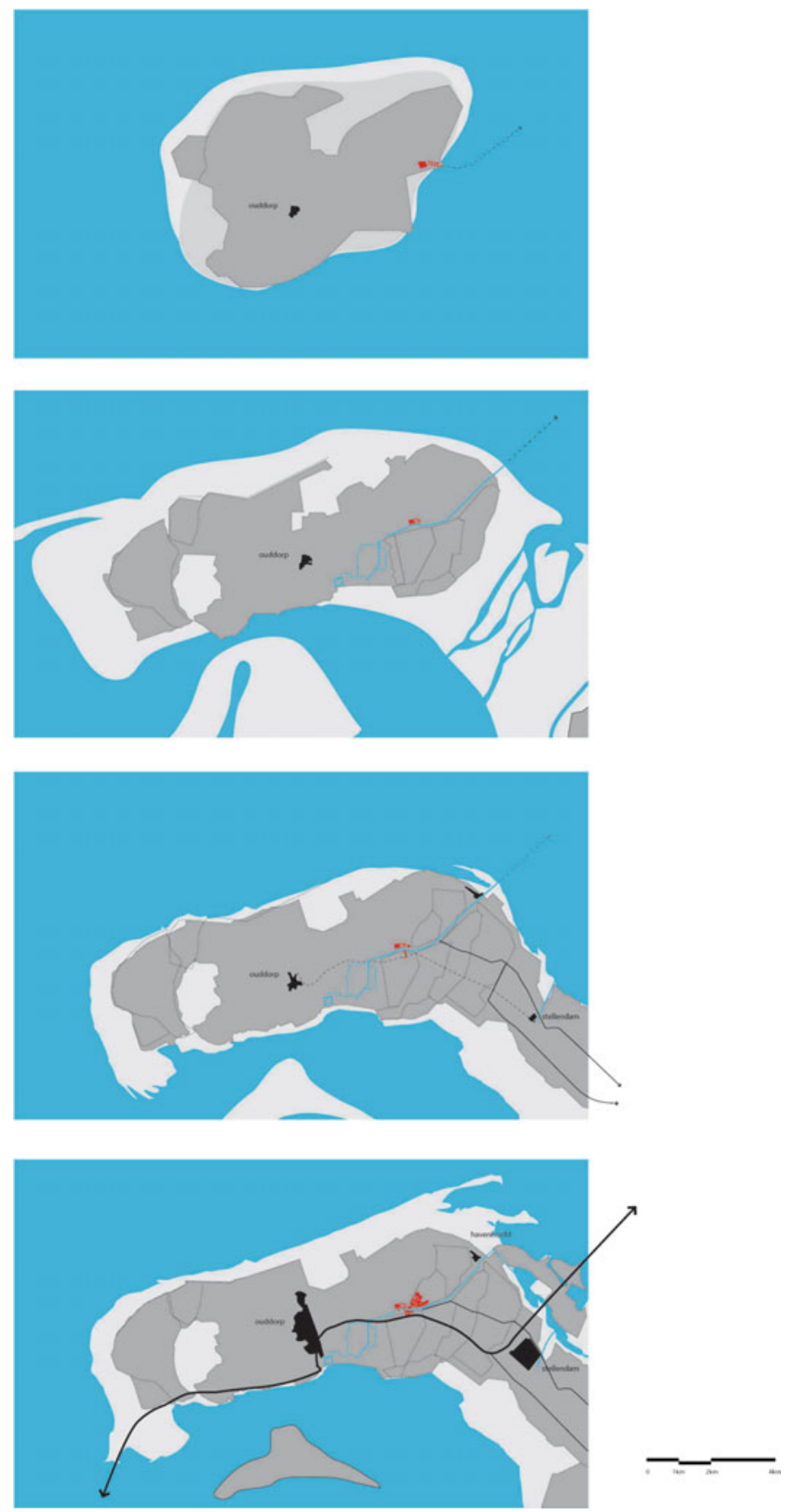

Fig. 3 Island Goeree in the Dutch Southwest delta, in four stages: 1500, 1700, 1900, and 2000. Drawings by Wout Smits, Delft University of Technology; released under a Creative Commons Attribution-NonCommercial-NoDerivatives 4.0 International License 


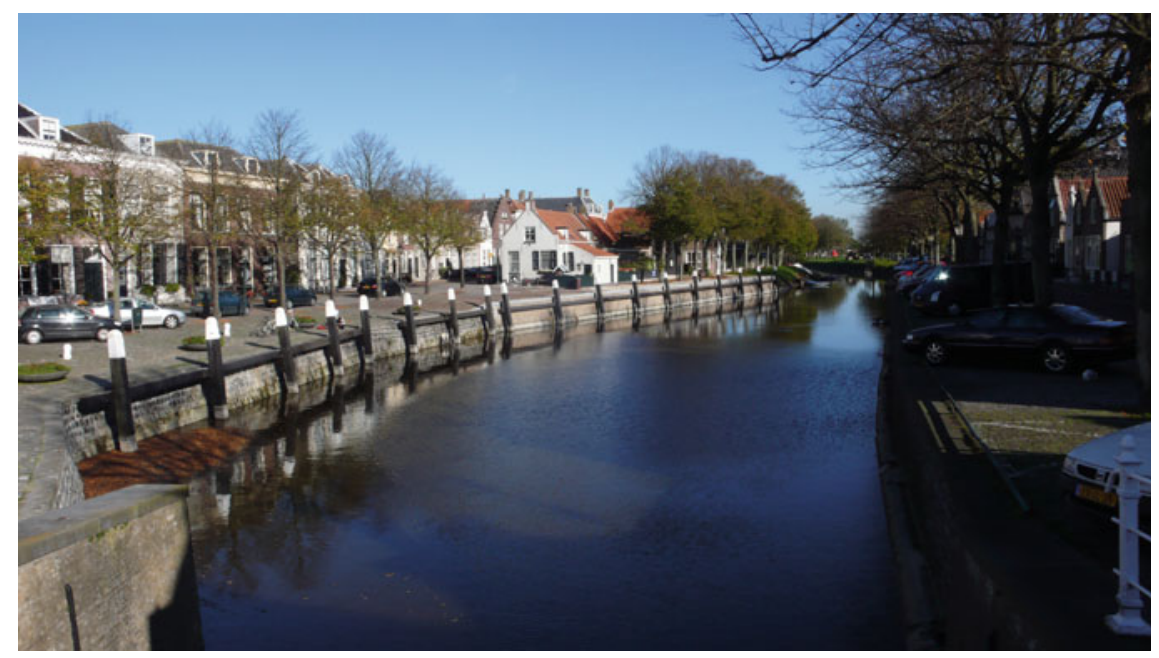

Fig. 4 Town of Goedereede, 2016. The harbor is not accessible anymore. Photograph by Han Meyer; released under a Creative Commons Attribution-NonCommercial-NoDerivatives 4.0 International License

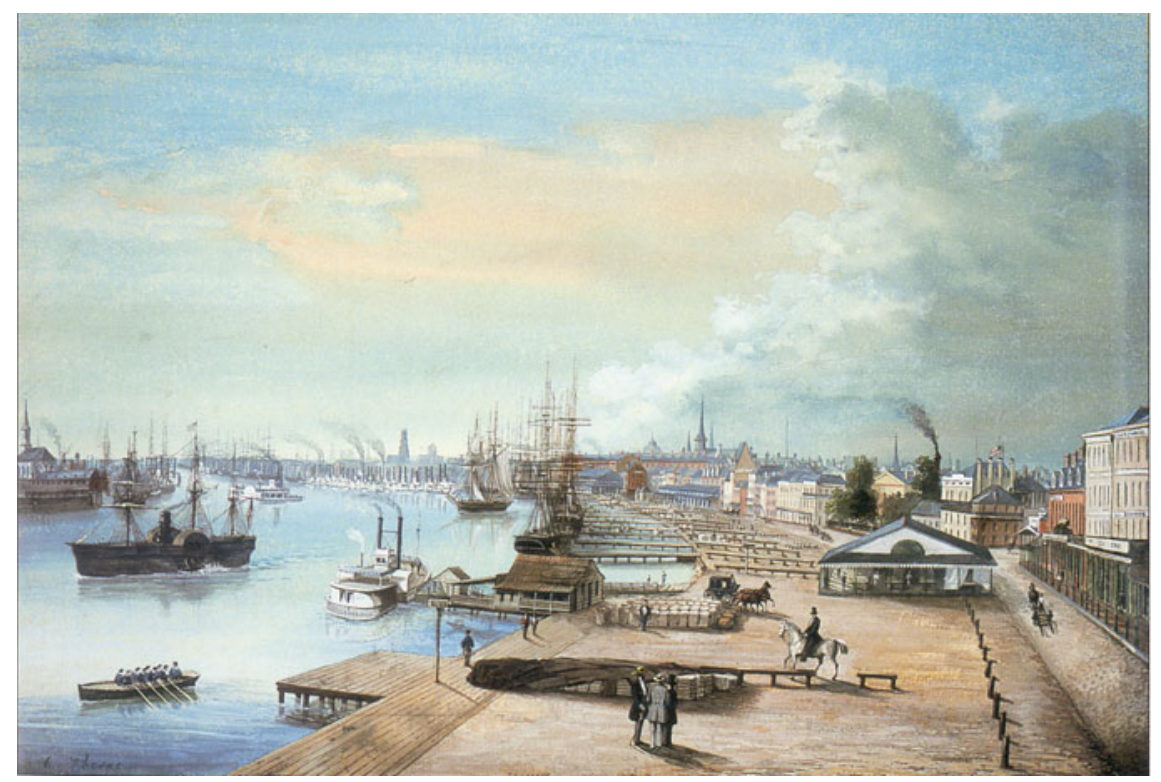

Fig. 5 New Orleans waterfront in 1859, painted by Adrien Persac. Source The New Orleans Historic Collection; released under a Creative Commons Attribution-NonCommercial-NoDerivatives 4.0 International License 


\section{The Destructive Role of Industrialization and the Colonization of Deltas}

In the mid-nineteenth century, steam power and the rise of nation-states created the conditions for large-scale transformations of delta landscapes. New, steam-powered machines were deployed to construct canals, dams, dikes, pumping stations, completely restructuring the complex delta landscapes into artificial and controlled water machines. The management of deltas and river systems became a concern of national states, and the other way around: The management of delta and river systems became a condition for nation-building. This is certainly true for the two nations with the largest expenses in water management, the USA and The Netherlands (O'Neill 2006).

As Mark Twain writes in his memoirs, the Mississippi River basin is 'the body of the nation' (Twain 1883). The basin of the river and its tributaries covers almost $70 \%$ of the national territory of the USA; historically, it 'sculpted the landscape, creating the flood plains, canyons, estuaries and deltas that underpin much of America's natural bounty' (Davis 2011). Moreover, this river system became the nation's most important transport network. After the Civil War of the 1860s, when nation-building became a prime priority for the US federal government, the US Army Corps of Engineers took responsibility for the management of the whole Mississippi River basin (Barry 1997; O’Neill 2006). It focused on improving navigation conditions by constructing levees and narrowing the river channel, creating faster currents which in turn cut deeper channels in the riverbed. The consequences for the delta and for New Orleans, situated in the heart of the delta, were huge. Narrowing the river substantially decreased the capacity of upstream flood plains for storing water, and thereby created higher water levels and a higher risk of flooding in the New Orleans region. The city constructed a high levee on the public waterfront to protect the city from the higher water, but in doing so they robbed the city of its public waterfront and its useful mud. Moreover, the construction of levees closed off the tributaries in the delta from the river, depriving them of a regular supply of freshwater and sediments necessary for the maintenance and resilience of the wetlands.

River sediments had built up the Mississippi River delta over 7000 years to $21,000 \mathrm{~km}^{2}$, but the new river management erased $4900 \mathrm{~km}^{2}$ (a full $23 \%$ of the land) in just a hundred years (Gramling 2012) (Fig. 6). Because of the role of wetlands as a buffer against storm surges, this loss made New Orleans substantially more vulnerable. At the same time, the population and geography of the city exploded with the exploitation of the oil and gas fields in the Gulf of Mexico. Giant pumping systems drained the marshlands, behind the natural levees of the river, to create dry building conditions for new urban extensions. But the pumping also created irreversible land subsidence, exacerbating the area's vulnerability to flooding (Campanella 2006, 2010; Waggonner et al. 2014).

The story of the Netherlands is even more extreme. Almost the whole country can be considered a delta plain, built up by the Rivers Rhine and Meuse since the last glacial age. From the independence war (1568-1648) to the Napoleonic domination (1795-1813), this territory was governed by the 'Republic of the Seven Provinces,' a 


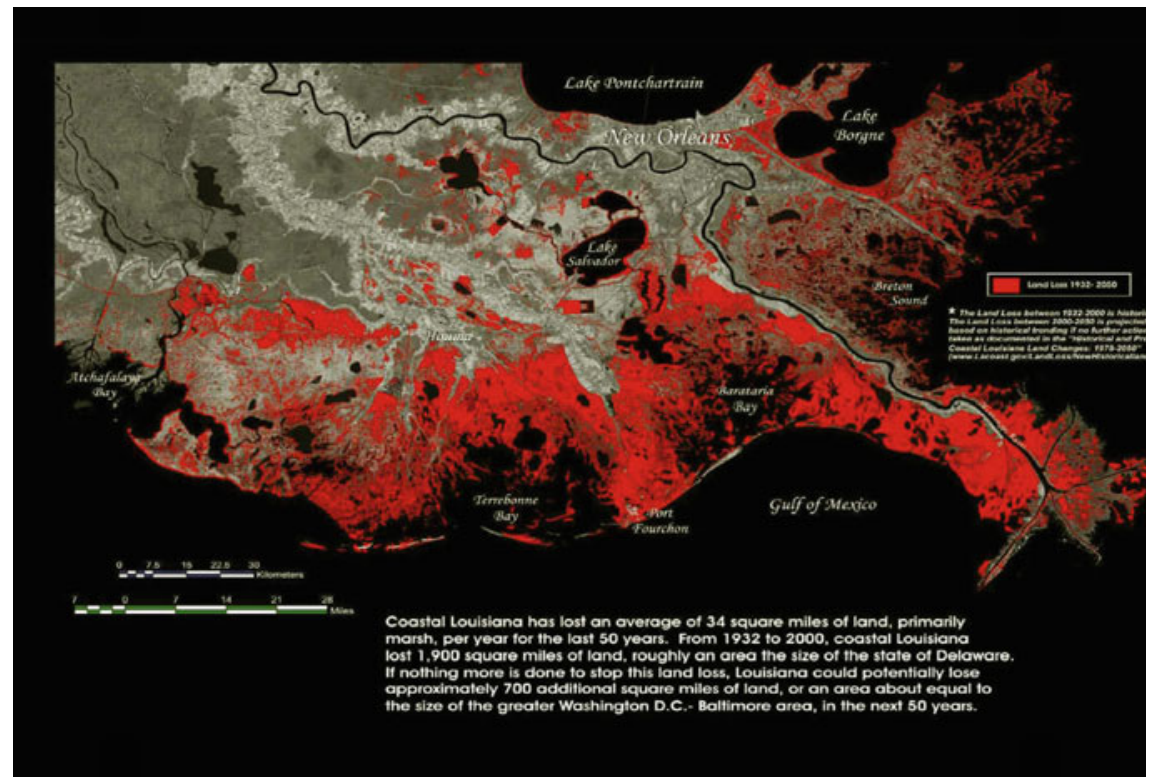

Fig. 6 Mississippi River delta; the red color indicates the expected land loss in the period 1932-2050. Source State of Louisiana; released under a Creative Commons AttributionNonCommercial-NoDerivatives 4.0 International License

loose federation of autonomous city-states and provinces. Many local water boards and polder districts managed water for their local territories. But they rarely coordinated their policies across administrative borders and often fought over jurisdiction with cities and provinces, and the central government of the federative republic was too weak to set overall policy. This situation changed with the introduction of a strong central government during the Napoleonic time and continued and strengthened afterward when the different states of the Netherlands became part of a unified nation-state. The creation of a national water agency (Rijkswaterstaat) in 1798 helped transform the Netherlands into an industrial economy in the nineteenth and twentieth century. Like the US Army Corps of Engineers, Rijkswaterstaat made channeling rivers a high priority, and it also dug new canals to the country's major ports, Rotterdam and Amsterdam. The new canals improved the accessibility of the ports and at the same time made room for the overflow from rivers in heavy rains, substantially reducing the flood risk in areas upstream. A crucial intervention in this respect was the construction of the Nieuwe Waterweg ('New Waterway') between Rotterdam and North Sea. It solved the problem of the silting up of the Nieuwe Maas ('New Meuse'), which was the mouth of both the Rhine and the Meuse. The Nieuwe Waterweg was a new, artificial river mouth, making the port of Rotterdam more accessible to ships and accommodating the discharge of the river water of Rhine and Meuse. But it also increased the influence of the sea and the rivers in the city of Rotterdam. The port 
and adjacent industries in the Rotterdam region grew explosively, as did the urban population in the polders behind the river dikes (Meyer 2017).

In the twentieth century, the large-scale dike construction and reclamation projects of the Zuiderzee works and Delta works created a solid flood defense system, part of larger projects to enormously increase both agricultural land and new national infrastructure. The Zuiderzee works (1925-1970) included a new 35-km closure dam (Afsluitdijk) and the transformation of the inland sea into $1700 \mathrm{~km}^{2}$ of new polders, increasing the size of the country by approximately four percent. The new IJsselmeer polders became an international showcase of modern, rationalized agriculture. The Delta works (1960-1990) included a series of dams and storm surge barriers in the Southwest delta, at the confluence of the Rivers Rhine, Meuse, and Scheldt (Fig. 7). The Delta works improved protection against floods in this region, created conditions for industrial development, and improved navigation routes between the ports of Rotterdam and Antwerp. The growth of the port of Rotterdam is linked closely to the construction of the Nieuwe Waterweg in the 1870s and to the Delta works. The port area is built on approximately 8.000 ha of artificially raised land and 6000 ha of harbor basin. The height of the land varies 3-6 m above mean sea level. A significant part of the port area (Maasvlakte 1 and 2, appr. 3000 ha) is new land reclaimed from the sea.

The Zuiderzee works and Delta works combined dike construction and land reclamation with the construction of new roads, which tied the different, sometimes very isolated, parts of the delta territory together. The system of hydraulic works not only delivered safety but also economic prosperity and national unification. However, in the 1970s, the disadvantages of this artificial delta machine became the object of public and political debate: ecological degradation, salinization, and substantial land subsidence.

It is a misunderstanding to consider these large-scale hydraulic works as inevitable and necessary projects, as products of a 'natural' Dutch culture. Both projects were already highly controversial from the beginning and the subject of serious scientific, societal, and political debates over many years (Meyer 2017). In the 1950s, the growth of the port along the mouth of the river Nieuwe Maas was considered a risky adventure. Johan van Veen, the secretary of the Delta Committee and 'godfather' of the Delta works, advocated that the country concentrates modern port facilities in the coastal zone of the river mouth. He warned against extending the port upstream on the grounds that it would require deepening the navigation channel in Nieuwe Waterweg and Nieuwe Maas, increasing the effects of tides and storm surges on Rotterdam and of salinization of the hinterland. The province of South Holland argued for concentrating the industrial port south of Rotterdam, partly for the same reasons, partly to maintain natural coastal areas, and partly to avoid dividing the province with a 50-km long strip of industrial port facilities.

The national government and the Port of Rotterdam did not take these arguments seriously and pushed their own preference for completely industrializing the land along the river mouth. But van Veen was right: Dredging the river mouth increased the vulnerability of the Rotterdam area to floods. So the country had to construct one more Delta work: the Maeslant barrier. 


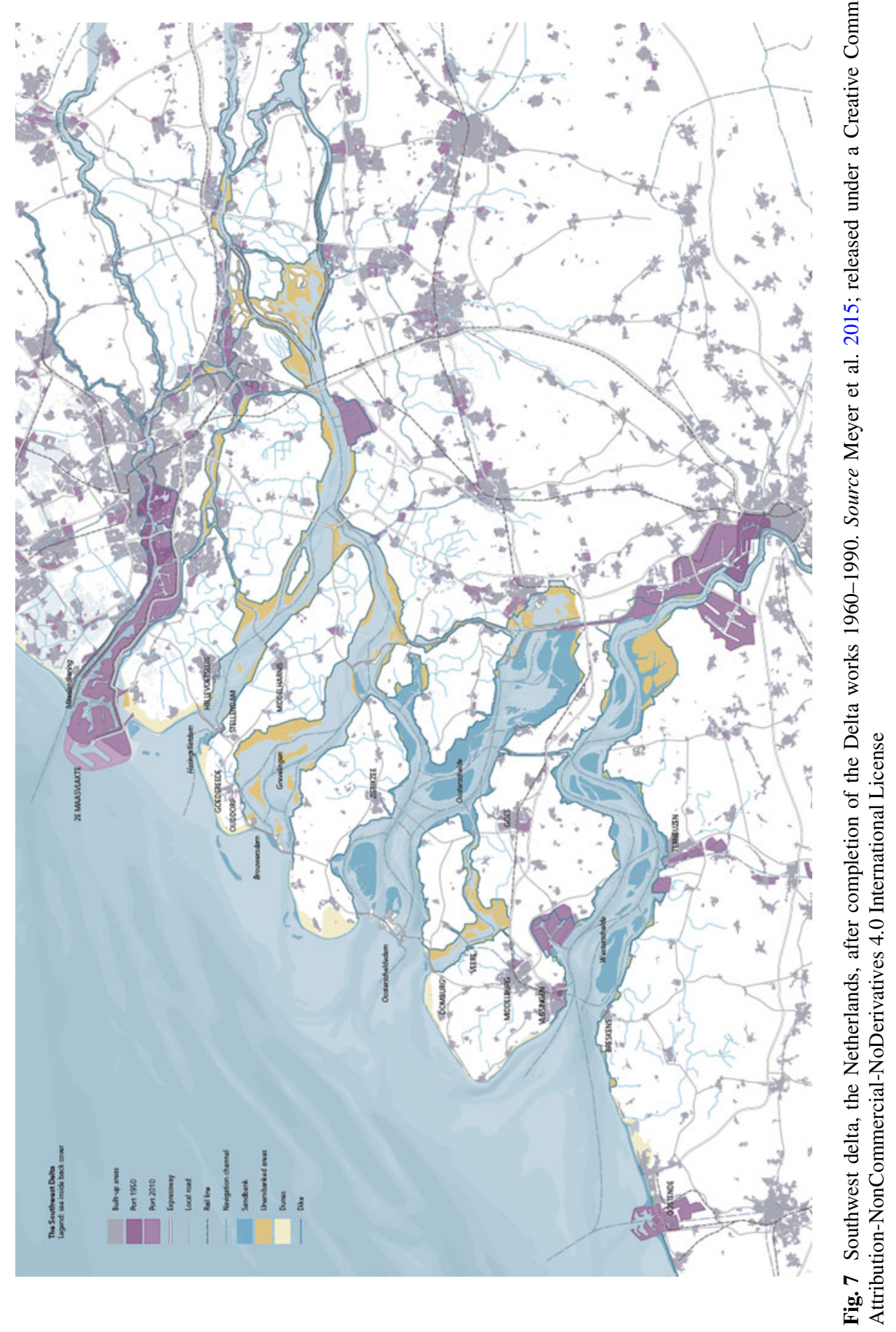


Despite these systemic problems, the idea of transforming delta landscapes into industrial machines, inspired by the examples of the Netherlands and the Mississippi River delta, was distributed and applied all over the world, with predictably disastrous consequences (Meyer and Nijhuis 2014). During the twentieth century, mass urbanization in Asian, South American, and African deltas put those deltas into crisis. The Intergovernmental Panel on Climate Change (IPCC 2007) identified three major consequences of the depletion of the natural systems of deltas by human intervention. First, dramatic losses of ecosystem services decreased the formative power of the deltas. Intense urban and industrial land use, drainage, dredging, reclaiming, and damming have deprived the land-water ecosystems of their capacity to absorb the impact of extreme events and to restore balance after disturbances. Moreover, upstream damming and reservoirs have depleted sediment resources in rivers, deeply eroding delta and coastal landscapes (Mulder et al. 2011; Campanella 2010). In their research on 40 deltas around the world, Ericson et al. show that sediment trapping upstream is the main cause of erosion in 27 of these 40 deltas (Ericson et al. 2006). Second, intense drainage and (industrial use of) groundwater extraction caused land subsidence. Urban and agricultural territories in many deltas (including the Nile delta, Rhine-Meuse delta, Mississippi River delta, Jakarta, etc.) have dropped substantially below sea level, making these territories more vulnerable to flooding. This process is still going on in many urbanizing deltas, leading to uncontrollable flood risk (Nicholls et al. 2007). Finally, intense dredging, land subsidence, and sea-level rise combine to diminish the supply of fresh water, increasing salinization of the local water. Many urbanizing deltas find themselves in a paradoxical situation: surrounded by water, but lacking fresh water for drinking and irrigation (Tessler et al. 2015).

Together, these technologies have vastly increased the vulnerability of deltas to flooding and further salinization, even as external conditions are worsening because of climate change: sea-level rise, increase of peak discharges of rivers, and more extreme precipitation. Recently, the UN-Habitat III Forum agreed in its 'New Urban Agenda' that we must radically change our approach in all urbanized deltas (Meyer and Peters 2016). Ecosystem services should be revitalized; their capacity to contribute to the recovery of delta territories after disturbances should be recovered. This revitalization must occur in other natural land-water transitions as well: beach and dune systems, salt marsh systems, coastal coral reefs systems, and mangrove forest systems. In the long term, the underlying strategy of 'building with nature' will restore conditions in which delta regions can adapt to climate change continuously. The formative power of nature itself is the strategy's foundation.

\section{Toward a Different Approach to Urbanizing Deltas}

The increasing awareness of the necessity of a change to a different approach in urbanizing deltas has resulted in new initiatives in several delta regions. 


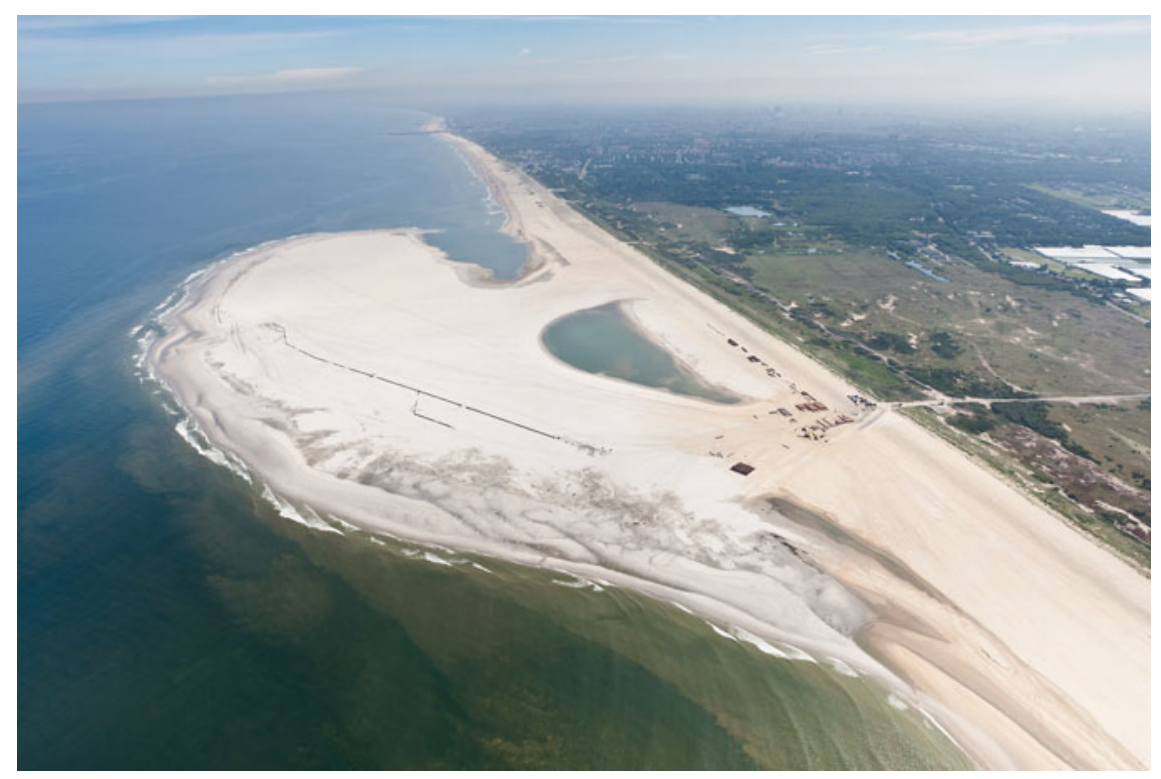

Fig. 8 Sand engine, coast of South Holland, 2011. Source Rijkswaterstaat; released under a Creative Commons Attribution-NonCommercial-NoDerivatives 4.0 International License

Public and political debates in the Netherlands on the urgency of drastically changing water management and flood defense led to the agreement of the Dutch government on a report of the Dutch Delta Committee in 2008, entitled 'Working together with water.' Based on this report, the government started a new 'Delta Program' in 2014, which formulated new standards based upon worst-case scenarios of climate change and sea level rise to 2050 (Delta program 2014).

Linked to this policy, the government developed and implemented two programs that sought to 'build with nature': Coastal Weak Links (2003-2012) and Room for the River (2005-2015). Both programs included new experiments, like the 'sand engine' at the coast of South Holland (Fig. 8) and forty projects in the river area that extended the floodplains of the rivers. Instead of raising dikes and destroying vulnerable ecosystems, the new projects created more room for water and strengthened the ecosystems of land-water transitions. The recovery of natural systems is essential to reversing erosion and land subsidence and stabilizing the delta landscape.

A central question is if and how this new approach of building with nature can be attuned to a continuation of the industrial port in the heart of the Rotterdam delta region. The Port area is one of the most extreme examples of a complete land transformation: At approximately 14,000 ha, it renders the previous landscape invisible. Buried under 3-6 $\mathrm{m}$ of sand, the previous landscape was an interesting and dynamic part of the delta, with different forms of sedimentation and erosion; it was considered one of the richest natural environments of the Netherlands. The Rotterdam Port Authority has started to take this hidden history seriously and to investigate how 
to restore its original dynamics. It seeks to set an international benchmark as the greenest and cleanest port of the world (Port Authority Rotterdam 2014), in part by closely collaborating with both the City of Rotterdam and the World Wildlife Fund. Together they have developed a strategy of 'an open port in a natural delta' (World Wildlife Fund/Port Authority Rotterdam 2016). Part of this strategy is the plan 'The river as tidal park' (Fig. 9), which would achieve flood safety, ecological recovery, and urban recreation space by turning the steep and hard quay walls of the river embankments into gentle slopes of green marshlands. This plan is interesting from the point of view of improving the river's ecosystem and creating a greener environment in the city, but also from the point of view of cultural heritage: It reminds us that there is a longer history of relation between city and river than the remains of the industrial port suggest.

In the long term, restoring the mouth of the river as a tidal estuary would mean that the whole riverbed can silt up in the course of time, forming sandbanks and small islands.

This will be an important contribution to the safety of the Rotterdam area. Instead of a storm surge barrier, natural dynamics can take over the role of protecting the hinterland. The river can discharge its redundant water into the larger estuaries south of Rotterdam. In the long term, too, this 'building with nature' option for the Rotterdam region would diminish the power of storm surges over urbanized areas. It must be acknowledged that the city would lose many of its port-related river quays and would no longer be able to use the river as a deepwater channel. Both aspects would be quite difficult for those who consider the quay walls as important cultural heritage of the port city, and for those who want to maintain the river as a deepwater channel.

But the future of the land use in the port territory is very uncertain because of the unknown effects of energy transition. At this moment, more than $60 \%$ of the port territory is used by facilities for the storage, transshipping, or processing of fossil fuels. Changing to a zero-fossil economy will end these uses and will mean fundamentally reconsidering the land use in the port area. It creates the possibility of abandoning the deepwater channels in most of the port area and concentrating the deep sea port in the Maasvlakte ('Meuse Plain') area-as van Veen argued in the 1950s.

Then, it would be easy to implement the 'river as a tidal park' plan, leading to the silting up of the river mouth, creating new islands and wetlands alongside the embankments, and leading to more safety by reducing tidal currents in the river mouth. The result would be a rather radical change of the urban image of Rotterdam, from a hard-core industrial port city to a more gentle, green-blue, and-environmentally friendly region. This is only possible when we are able to consider the industrial period as relatively short episode in Rotterdam's history, not the central characteristic of its past and present identity.

Other port cities are also struggling to form new policies and images. In the Mississippi River delta, the Louisiana Coastal Mitigation Guidebook by the State of Louisiana (2008) proposes approaches for the Mississippi River delta and the Greater New Orleans region that resemble the plans for Rotterdam. Repairing former river branches in the delta by breaking through the levees along the main channel is 

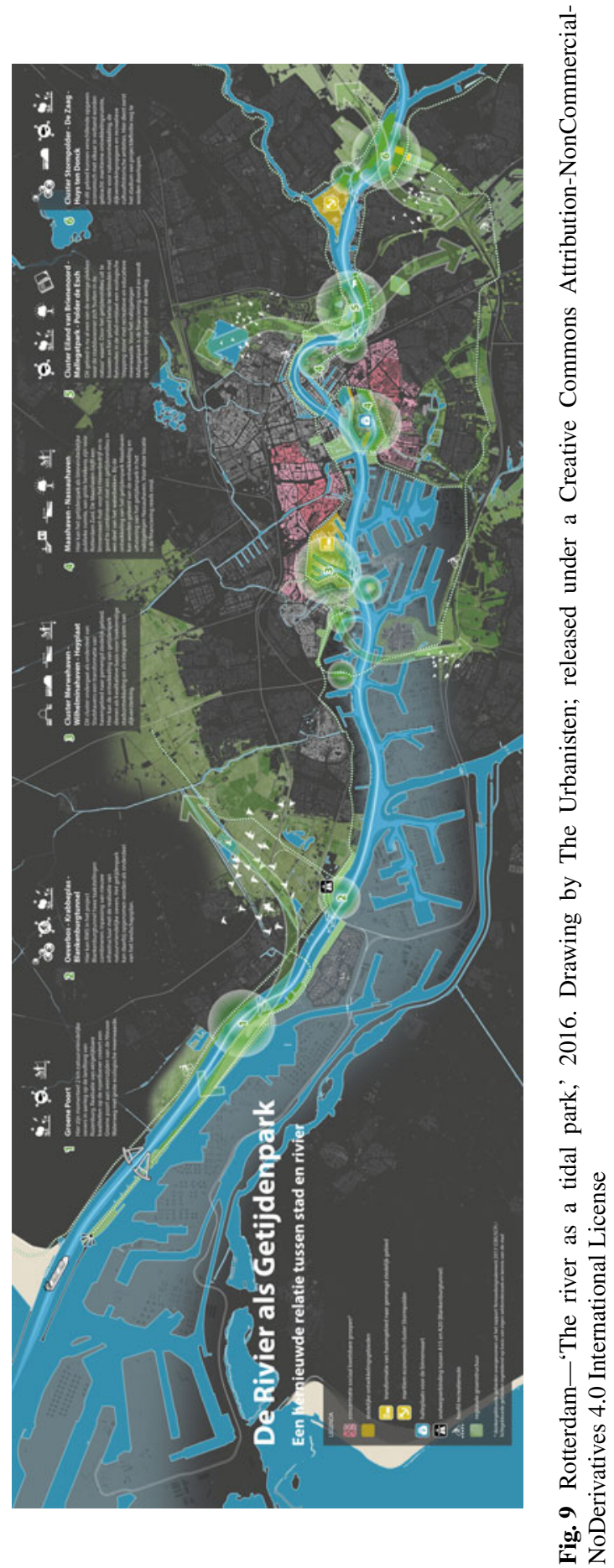


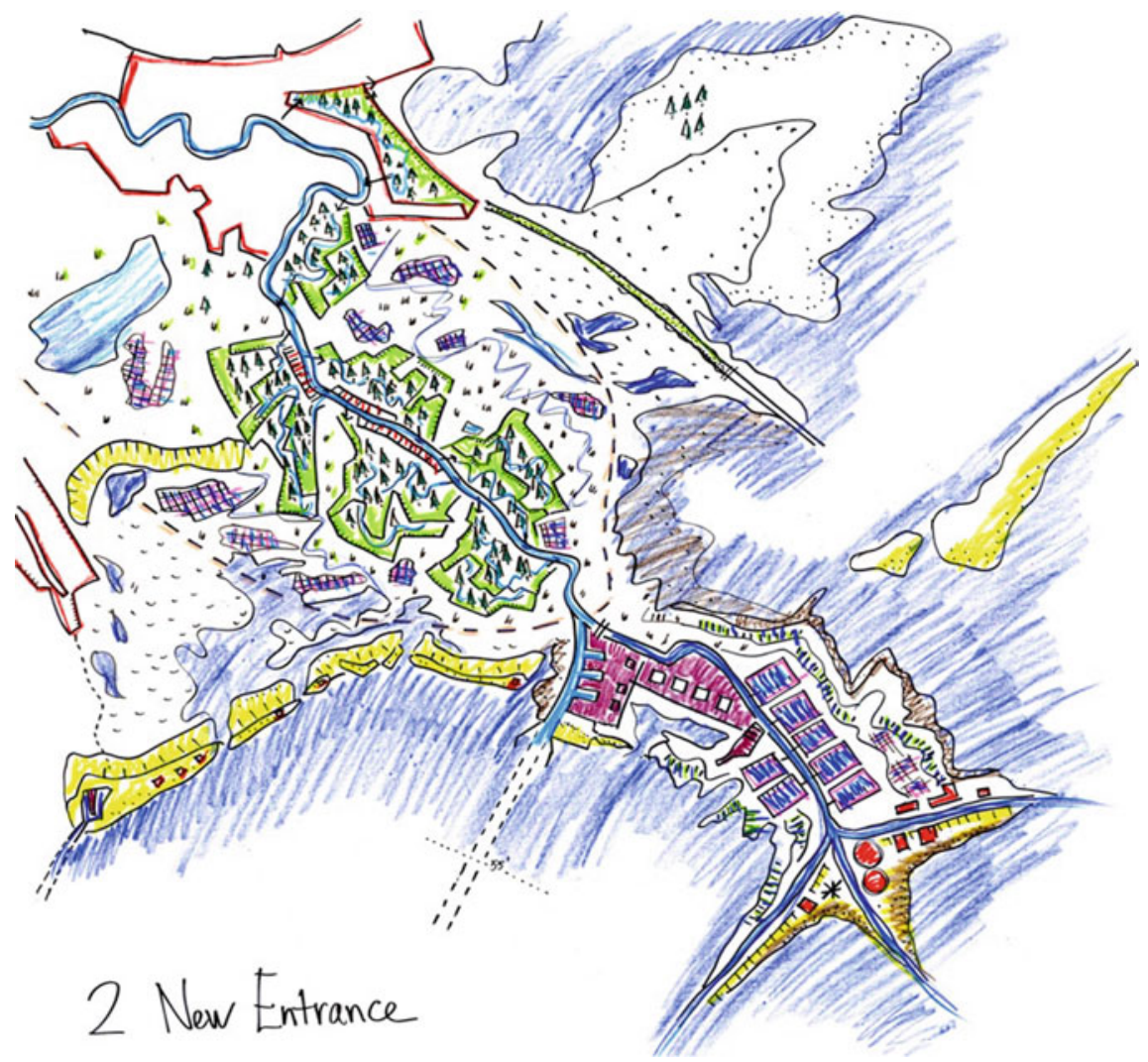

Fig. 10 Mississippi River delta, design sketch exploring the possibility of a displacement of the port of New Orleans toward the mouth of the river. Drawing by Hoal et al. 2014b; released under a Creative Commons Attribution-NonCommercial-NoDerivatives 4.0 International License

necessary for the recovery of the wetlands. In the long term, the state also suggests moving the Ports of New Orleans and South Louisiana from their current location upstream from New Orleans, to the mouth of the river downstream from the city. Design studies, showing the possibilities of moving the ports to the deepwater areas outside the delta, have been executed by design teams for the competition 'Changing Courses' (Hoal et al. 2014a) (Fig. 10). They show that sea vessels will not need to pass the City of New Orleans, which means that the maintenance of the deepwater channels in and around the city would no longer be necessary. This would significantly reduce the vulnerability of the city to storm surges.

The European port cities Hamburg and Antwerp are also struggling with their vulnerability to flooding due to frequent dredging of the navigation channels in the estuaries of the rivers Elbe and Scheldt. Studies on reducing this vulnerability all point in one direction: repair of the natural estuaries and an end to dredging (Stokman et al. 2010; Meire and van Dyck 2012). As this will make these estuaries inaccessible to 
large-size sea vessels, studies recommend that deepwater ports be constructed in deepwater locations, like the Maasvlakte in Rotterdam or the Yangshan deep-water port island in the Shanghai region in China. Ending dredging would also make it possible to make the river a tidal park and to repair the historic remains of estuary flood plains and wetlands in the river mouths.

\section{Conclusions: Toward a Rehabilitation of the Heritage of Adaptation}

Cultural heritage is neither neutral nor objective; it is a choice, depending on which story we consider important. We choose to maintain a series of buildings, objects, and landscapes, to tell a particular story about the past. The argument of this chapter is that we need a new type of story, one that considers history not as a linear process, but as a sequence of stages, each characterized by specific economic, technical, societal, and climatological conditions. The transition from one stage to another has sometimes resulted in reclaiming new land from the sea; sometimes it resulted in a different economy; and sometimes it resulted in rebuilding cities in a different location. The material heritage of each of these cultures can be made more visible in the official cultural heritage campaigns. The opening of this chapter discussed the example of Goedereede, showing how this town adapted to changing conditions (the silting up of the navigation channels) by changing from a maritime to an agricultural economy. The current town, with its remarkable mixture of merchant's houses and farm buildings, is still a jewel of cultural heritage, showing the capacity of a community to adapt to changing conditions. More attention to examples of adaptation will help us understand the current necessity of an adaptive approach to delta regions and to consider it as a new stage in a long historic process of many centuries. Repairing the dynamic elements of the delta, like wetlands and flood plains, should be an important aspect of a cultural heritage policy even in urbanized and port areas.

Changing our approach does not mean we should forget or deny the importance of large hydraulic works of the industrial age. But we should reframe them in a critical perspective, as parts of a specific period dominated by an industrial economy and its ideology.

Ports and port cities play a crucial role in the change to an adaptive approach in delta regions. Too much emphasis on the close historic relation between industrial port and city and too much emphasis on the short-term interests of stakeholders in the current port territories can blind us to the necessity of radical but necessary choices that will lead to more sustainable and adaptive port cities in the future. Now we find ourselves in another stage of fundamental transition: of the economy, the energy supply, and the climate. Ports, as hubs of transshipment and processing of fossil fuels, have to radically change their role. It is the right moment to link their reconsideration with the move to a more adaptive approach to the natural dynamics of the delta territories. The town of Goedereede can be considered a small-scale 
forerunner of how to navigate the large-scale transition facing the Rotterdam port area in the next fifty years.

\section{References}

Barry JM (1997) Rising tide. The great Mississippi flood of 1927 and how it changed America. Simon \& Schuster, New York

Bradshaw M, Weaver R (1995) Foundations of physical geography. Wm.C.Brown Publishers, Boston

Buisman J (1995/2016) Duizend jaar weer, wind en water in de Lage Landen, zes delen. Van Wijnen, Groningen

Campanella R (2006) Geographies of New Orleans. Urban fabrics before the storm. New Orleans

Campanella R (2010) Delta urbanism. American Planning Association, New Orleans, Chicago \& Washington

Colten GE (ed) (2000) Transforming new Orleans and its environments: centuries of change. University of Pittsburg Press, Pittsburg PA

Committee Delta (2008) Working together with water. Ministry of Infrastructure, The Hague

Davis M (2011) Nation needs a fresh view of its rivers. https://gulfhypoxia.net/2011/08/23/

de Hullu J, Verhoeven AG (eds) (1920) Tractaet van Dyckagie. Waterbouwkundige adviezen en ervaringen van Andries Vierlingh in de Rijks Geschiedkundige Publicatien. Martinus Nijhoff, Den Haag

Ericson JP, Vörösmarty CJ, Dingman SL, Ward LG, Meybeck M (2006) Effective sea-level rise and deltas: causes of change and human dimension implications. Glob Planet Change 50(1-2):63-82

Gramling C (2012) Rebuilding wetlands by managing the muddy Mississippi. Science 335(6068):520-521

Hoal J, Mins T, Hoeferlin D, de Koning R, Donahue MJ, Etheridge D, Huthoff F, Hunter T, Visser J, Kolker A, Barneveld H, Buenano A, Berlin J, Coburn K, Degenaro N, de Vriend H, Meyer H, Jonkman B, Lyon L, McCorquodale JA, Nepf H, Peters B, Reed C, Taylor Robinson B, SalahMars S, Slaughter S, Weiss JP, Ying K (2014a) Studio Misi-Ziibi. Contribution to changing course: navigating the future of the lower Mississippi River Delta. https://www.h3studio.com/ competition/

Hoal J, Mins T, Hoeferlin D, de Koning R (2014b) Missi-Ziibi. 3 strategies for the Mississippi river delta, unpublished

Jan Mulder PM, Hommes S, Horstman EM (2011) Implementation of coastal erosion management in the Netherlands. Ocean Coast Manag 54:888-897

King FH (1911) Farmers of forty centuries. Permanent agriculture in China, Korea and Japan. Organic Gardening Press, Emmaus (Penn)

Meire P, van Dyck M (2012) Naar een duurzaam rivierbeheer. Hoe herstellen we de ecosysteemdiensten van rivieren? De Schelde als blauwe draad. UPA, Antwerpen

Meyer Han, Nijhuis Steffen (2014) Urbanizing deltas in transition. Techne Press, Amsterdam

Meyer H, Bregt A, Dammers E, Edelenbos J (eds) (2015) New perspectives on urbanizing deltas. A complex adaptive systems approach to planning and design. MUST Publishers, Amsterdam

Meyer H (2017) The state of the delta. Engineering, urban development and nation building in the Netherlands. VanTilt, Nijmegen

Meyer H, Peters R (2016) A plea for putting the issue of urbanizing deltas on the new urban agenda, report for UN-Habitat III, commissioned by Ministry of Foreign affairs, The Netherlands, Delta Alliance/Delft University of Technology

Nicholls RJ, Wong PP, Burkett VR, Codignotto JO, Hay JE, McClean RF, Ragoonaden S, Woodroffe CD (2007) Coastal systems and low-lying areas. Climate change 2007: impacts, adaptation and vulnerability. In: Parry ML, Canziani OF, Palutikof JP, van der Linden PJ, Hanson CE (eds) 
Contribution of working group II to the 4th assessment report of the intergovernmental panel on climate change, Cambridge University Press, Cambridge, UK, pp 315-356

O'Neill KM (2006) Rivers by design. State power and the origins of U.S. flood control. Duke University Press, Durham

Port Authority Rotterdam (2014) Port Compass 2030. http://havenkompas2030.nl/

Stokman A, Köhler B, Rabe S, von Seggern H, Schröder G, Schulz J, Thorhauer T, Zeller S (2010) Tideelbebuch. Landschafts- und stadtplanerische studie zur projekbezogenen umsetzung des tideelbeprojekts. Hamburg Port Authority, Hamburg

Stulp B (2011) Verdronken dorpen in Nederland, deel 5. Falstaff Media, Hoofddorp

Tessler ZD, Vörösmarty CJ, Grossberg M, Gladkova I, Aizenman H, Syvitski JPM, FoufoulaGeorgiou E (2015) Profiling risk and sustainability in coastal deltas of the world. Science 349/638:638-643

Twain M (1883) Life on the Mississippi. James R. Osgood \& Co., Boston. Republished 2000. Dover Publications Inc., Mineola, NY

Upton D (2008) Another city. Urban life and The New American Republic. Yale University Press, New Haven

Waggonner, Ball Architects (eds) (2013) Greater New Orleans Urban Water Plan. Greater New Orleans Inc., New Orleans. www.livingwithwater.com

Waggonner D, Dolman N, Hoeferlin D, Meyer H, Schengenga P, Thomaesz S, van den Bout J, van der Salm J, van der Zwet C (2014) New Orleans after Katrina. Building America's water city. Built Environ 40(2):281-299

World Wildlife Fund/Port Authority Rotterdam (2016) Een open haven in een natuurlijke delta. https://www.portofrotterdam.com/sites/default/files/open-haven-in-natuurlijke-delta.pdf

Han Meyer is Professor of Urban Design at Delft University of Technology. His work focuses on the fundamentals of urbanism and on Delta Urbanism. His recent books include Urbanizing Deltas in Transition (co-edited with Steffen Nijhuis, Amsterdam Techne Press, 2014) and The State of the Delta (VanTilt 2017). A forthcoming book is Urbanism-Fundamentals and Perspectives (VanTilt 2018).

Open Access This chapter is licensed under the terms of the Creative Commons AttributionNonCommercial-NoDerivatives 4.0 International License (http://creativecommons.org/licenses/bync-nd/4.0/), which permits any noncommercial use, sharing, distribution and reproduction in any medium or format, as long as you give appropriate credit to the original author(s) and the source, provide a link to the Creative Commons license and indicate if you modified the licensed material. You do not have permission under this license to share adapted material derived from this chapter or parts of it.

The images or other third party material in this chapter are included in the chapter's Creative Commons license, unless indicated otherwise in a credit line to the material. If material is not included in the chapter's Creative Commons license and your intended use is not permitted by statutory regulation or exceeds the permitted use, you will need to obtain permission directly from the copyright holder.

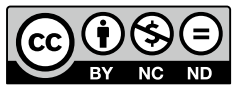

